Revue Française de Civilisation Britannique

XXII-1 | 2017

The Book of Common Prayer : Studies in Religious

Transfer

\title{
In Search of a Liturgical Patrimony: Anglicanism, Gallicanism \& Tridentinism
}

A la recherche d'un patrimoine liturgique: anglicanisme, gallicanisme et tridentinisme

Peter M. Doll

(2) OpenEdition

Journals

Electronic version

URL: http://journals.openedition.org/rfcb/1236

DOI: $10.4000 /$ rfcb.1236

ISSN: 2429-4373

Publisher

CRECIB - Centre de recherche et d'études en civilisation britannique

Electronic reference

Peter M. Doll, «In Search of a Liturgical Patrimony: Anglicanism, Gallicanism \& Tridentinism », Revue Française de Civilisation Britannique [Online], XXII-1 | 2017, Online since 02 May 2017, connection on 01 May 2019. URL : http://journals.openedition.org/rfcb/1236 ; DOI : 10.4000/rfcb.1236

This text was automatically generated on 1 May 2019.

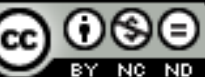

Revue française de civilisation britannique est mis à disposition selon les termes de la licence Creative Commons Attribution - Pas d'Utilisation Commerciale - Pas de Modification 4.0 International. 


\title{
In Search of a Liturgical Patrimony: Anglicanism, Gallicanism \& Tridentinism
}

\author{
A la recherche d'un patrimoine liturgique: anglicanisme, gallicanisme et \\ tridentinisme
}

Peter M. Doll

1 The non-Roman catholicity of the Anglican liturgical tradition, which appeals so much to the Old Catholics, also provides a door for Roman Catholics to a half-forgotten Catholic patrimony. One of the most remarkable features of the pontificate of Benedict XVI was his determination to recover some of richness of liturgical tradition that he believed had been lost in the reforms since Vatican II. ${ }^{1}$ In 2007 he declared in the motu proprio Summorum Pontificum that both the Novus Ordo post-Vatican II rite of the Mass and the 1962 revision of the Tridentine rite were legitimate forms of the one Roman Rite, thereby breaking at a stroke the tradition that there should be only one version of the Roman Rite for the universal Church. In 2009 Benedict issued in addition an apostolic constitution entitled Anglicanorum coetibus providing for personal ordinariates for Anglicans entering into full communion with the Roman Catholic Church. ${ }^{2}$ In it, he made a remarkable provision for a distinct Anglican liturgical character within the Roman Church:

2 Without excluding liturgical celebrations according to the Roman Rite, the Ordinariate has the faculty to celebrate the Holy Eucharist and the other Sacraments, the Liturgy of the Hours and other liturgical celebrations according to the liturgical books proper to the Anglican tradition, which have been approved by the Holy See, so as to maintain the liturgical, spiritual and pastoral traditions of the Anglican Communion within the Catholic Church, as a precious gift nourishing the faith of the members of the Ordinariate and as a treasure to be shared.

3 By making this provision for an Anglican use within the Western Church, he opened the way for even greater diversity of liturgical culture. When Benedict allowed both 'ordinary' and 'extraordinary' forms of the one Roman rite, he expressed the hope that 
the two might be 'mutually enriching.' ${ }^{3}$ By adding the Anglican liturgical tradition to the mix, his explicit intention was that the 'liturgical, spiritual and pastoral traditions of the Anglican Communion' were 'a treasure to be shared' with the rest of the Church. What, then, is the character of this Anglican tradition from which Benedict was confident that others should learn?

The very diversity of liturgical culture which these developments encourage is in fact a notable characteristic of the Anglican 'patrimony'. In addition to the reformed influences from Wittenberg, Geneva and Zurich, the Anglican liturgical tradition is also a throwback to older Catholic traditions lost to the centralizing spirit of Ultramontane Catholicism in the nineteenth century. Through most of its existence, members of the Church of England both before and after the Reformation have been influenced by developments in Continental Catholicism. Anglican and Catholic theologies have been influenced by parallel if sometimes divergent intellectual currents. Anglicanism is in many ways an English expression of the Catholic tradition known as 'Gallicanism'. ${ }^{4}$ In this context, Gallicanism denotes that expression of Catholicism (particularly associated with the Church of France but also influential elsewhere) with deep roots in national character and local liturgical and devotional traditions; a strong sense of identity with the undivided Church of the early Fathers; and a looser, conciliar, collegial structure in which authority is shared between the Pope and diocesan bishops. These characteristics bear a strong resemblance to what has been known as 'classical Anglicanism'. Tridentinism, or Ultramontanism, on the other hand, looks directly to the papacy and the contemporary Roman Church for its source of authority and identity.

This paper focuses on the architectural setting of the liturgy because once the text of the Book of Common Prayer has been agreed, all subsequent liturgical decisions are about how that text is to be performed: what is the form and decoration of the church building; how do clergy and laity relate and move within the space; what vestments are worn and what music sung or played. The development of the performance of the liturgy has never been tied down to Cranmer's theology; theologies of worship developed that were at variance with the official text if not in contradiction to it.

6 The scholarly assessment of Anglican worship in the century after the death of Henry VIII has been very much caught up in the various conflicting approaches to the reigns of the Tudors and Stuarts. Kenneth Fincham and Nicholas Tyacke have summarised revisionist scholarship of the last thirty years on the architectural setting of the Eucharist in this period. ${ }^{5}$ The first Book of Common Prayer (1549) in the reign of King Edward VI allowed the retention of Eucharistic vestments and ceremonial. From the second Prayer Book of 1552 to the early seventeenth century, however (excepting the reign of Philip and Mary, 1553-58), the Puritan liturgical agenda dominated the church. Images were removed and decorated walls whitewashed, roods and lofts taken down (but screens largely left in place), and altars and altar steps removed, replaced by wooden communion tables set up table-wise (east and west) in the body of the chancel rather than altar-wise (north and south) at the east end. Typically the liturgy of the Word would be celebrated in the nave of the church. When the Eucharist was celebrated, clergy and people together would 'draw near with faith' by moving through the screen into the chancel to gather together around the communion table.

7 The only significant exception to this arrangement for the communion table was Queen Elizabeth's Chapel Royal, furnished with an altar set altar-wise, up steps and furnished with candles and a crucifix. Elizabeth's Injunctions of 1559 ruled that the 'holy table' 
should be 'set in the place where the altar stood' except at the celebration of communion, when it would stand in the midst of the chancel, but this rule was generally ignored. Rather than presiding over what has been seen as an Anglican via media, Elizabeth fought a largely unsuccessful campaign against the thoroughgoing iconoclasm of the Edwardian reaction against Mary's restoration of Catholicism. In this period, Elizabeth's was a lonely voice in the Protestant establishment to argue in favour of a traditional liturgical setting.

Just when the Puritan triumph seemed complete, however, there emerged in the last decade of Elizabeth's reign an 'avant-garde' of clergy, led by Richard Hooker and Lancelot Andrewes, who not only were committed to greater ceremonialism in worship but also increasingly questioned what passed for Puritan orthodoxy. For the avant-garde, it was not sufficient to reject ornaments and ceremonies simply because Roman Catholics had them. In common with many European scholars of diverse traditions, Hooker found justification for ceremonious worship from the precedent of the Jerusalem Temple. Of his Puritan opponents he wrote:

[They have] a fancy ... against the fashion of our churches, as being framed according to the pattern of the Jewish temple. ... So far forth as our churches and their temple have one end, what should let but that they may lawfully have one form?

The Temple was understood to be not simply the archetype of the Christian church building, it was also a model for civic planning and a means of articulating the symbiotic relationship between church and state. King Philip II of Spain's self-identification with King Solomon shaped the design of his monastery/palace El Escorial (1563-1584). The Spanish Law of the Indies of 1573 designated a model of civic planning based on the vision of Ezekiel (ch. 40) as interpreted by the Franciscan Nicholas of Lyra (d. 1349). ${ }^{7}$ The Spanish Jesuit theological and architectural scholars Juan Bautista Villalpando and Hector Prado published a monumental three-volume treatise on Ezekiel's vision of the Temple ${ }^{8}$ which influenced projects as diverse as the design of the English Puritan New Haven Colony in Connecticut (1639), ${ }^{9}$ the widely exhibited model 'Templo' built by Rabbi Jacob Judah Leon (ca. 1602-75), and ultimately the design of the Portuguese Great Synagogue of Amsterdam. ${ }^{10}$

The Temple tradition retained a unique power and significance in the Christian mind, and the Church of England made its own claim to that heritage. Even through much of the nineteenth century, a conscious link with the Temple was at the heart of church building. Queen Elizabeth's church orders of October 1561 insisted on the retention of chancel screens (standing for the Veil of the Temple hanging before the Holy of Holies) and that 'the tables' of the Decalogue (Ten Commandments) should 'be fixed upon the wall over the said communion board'. The tablets of the Ten Commandments were kept in the Ark of the Covenant in the Holy of Holies in the Temple, the throne of God's presence guarded by two cherubim (1 Kings 8.6). From the early seventeenth century the commandments were frequently augmented by brightly painted images of Moses and Aaron like that commissioned by Archbishop Whitgift for the chapel of his hospital at Croydon in 1601. ${ }^{11}$ In the church/temple typology, the chancel stood as the Holy of Holies in the Temple, the screen as the Veil, the altar as the Mercy Seat or throne of God where the Lord was present in the Eucharistic Mystery. The decorative motifs both in churches and popular prints were taken from the Temple: the tables of the Ten Commandments, the shekinah (depicted as a sunburst or glory because of its association with the Pillar of Fire), clouds, cherubim, the Tetragrammaton or Holy Name. All of these were symbols of the real 
presence of Christ in the Eucharist just as in the Temple they had pointed to the abiding presence of the Lord in the midst of his people. Altarpieces of the period would commonly bring together a number of these elements, as in the simple rural church of St Katherine, Chislehampton, Oxon (1763).

Historians have often distinguished Puritans and High Churchmen by associating Puritans primarily with the Word and preaching and High Churchmen with sacramental religion. Arnold Hunt has rightly argued that this is a false dichotomy..$^{12}$ Puritan and High Churchman alike held both preaching and the sacrament of the Eucharist in high regard. Even when their beliefs about the Eucharist coincided, however, they were divided by the kind of language they chose to use to express those beliefs. Reformed Patristic theologians like Lancelot Andrewes, Joseph Mede, William Laud, John Overall, Herbert Thorndike, and Jeremy Taylor chose to use the language of 'altar' and 'sacrifice' and 'oblation' drawn from their typological interpretation of Temple worship and from the Fathers and the liturgies of the Eastern Church, but Puritans rejected it because this was also the language of Roman Catholicism. ${ }^{13}$ The full title of the work which summed up the thought of the Patristic school, The Unbloody Sacrifice (1704) by John Johnson of Cranbrook, conveys precisely the points in contention: The Unbloody Sacrifice, and Altar, Unvailed and Supported, in which the nature of the Eucharist is explained according to the sentiments of the Christian Church in the four first centuries; Proving, That the Eucharist is a proper material Sacrifice, That it is both Eucharistic and propitiatory, That it is to be offered by proper officers, That the Oblation is to be made on a proper Altar, That it is properly consumed by manducation. ${ }^{14}$

These Biblical and Patristic ideals inspired architects including Christopher Wren (the son and nephew of Laudian high churchmen) and Nicholas Hawksmoor..$^{15}$ Sacramental theology also found visual expression in prints associated with popular commentaries on the liturgy. Jeremy Taylor's Eucharistic theology from his devotional favourite The Worthy Communicant (1660) is visually echoed in the frontispiece of Charles Wheatly's Rational Illustration of the Book of Common Prayer (1722), the standard Prayer Book commentary in the eighteenth century:

The church being the image of heaven, the priest, the minister of Christ; the holy table being the copy of the celestial altar, and the eternal sacrifice of the lamb slain from the beginning of the world being always the same; it bleeds no more after the finishing of it on the cross, but it is wonderfully represented in heaven, and graciously represented here; by Christ's action there, by his commandment here. ${ }^{16}$

The emphasis on the Temple was an extension of the concern of the churches of the Protestant and Catholic reformations for the witness of the Fathers of the early and undivided Church, each side appealing to patristic authority as justification for their doctrines and actions. ${ }^{17}$ The Fathers themselves looked to the Temple and the whole old Covenant as typological precedent for the Scriptures and church life of the New Covenant. Concern for the Primitive Church also excited interest among many Anglicans in the successors to the Eastern Fathers in the Orthodox Church. Anglicans looked to the Orthodox as fellow non-Roman Catholic Christians with a shared devotion to the primitive Church..$^{18}$ Lancelot Andrewes in his liturgical practice and patronage inspired the introduction of Orthodox liturgical practices into the Prayer Book rites. As Peter McCullough has observed, 'When Andrewes was thinking liturgically, he did so eastwardfacing, to ecumenical councils, Eastern liturgies, and even Eastern fittings. ${ }^{19}$ His influence is particularly evident in the Scottish liturgy of 1637 and the rites descended from it. If it 
is less evident in the 1662 Prayer Book, Andrewes' influence on English liturgical theology was nevertheless profound.

The movement in the early 1600s for the beautification of churches anticipated the Laudian reforms of the 1630s, with their emphasis on the 'beauty of holiness'. This artistic movement was in tension between a continuity in identity with the pre-Reformation Church in England (with a strong strain of gothic survivalism) and the exciting but decidedly theologically risky world of the continental baroque. ${ }^{20}$ As the use of images become more common in churches, so English artists turned to prints readily available from the Continent for inspiration and guidance. Biblical images by Catholic artists made widely available in prints particularly from Flanders were translated into stone, plaster, wood, and glass in English churches and houses alike. Through these prints, some of the symbols most powerfully connected with the Jesuits and the Tridentine reforms became part of the common visual currency in England, losing any of the negative connotations that might have been associated with their ultimate source. The Jesuit motif of the flaming heart, of the IHS (the sacred monogram of Holy Name of Jesus), of the Shekinah (the Hebrew term for the glorious presence of the Lord) depicted as a sunburst all came to be commonly used in Anglican contexts: architectural elements, plate, vestments, and devotional illustrations. Most ironic of all, the very emblem of the Society of Jesus became the most common symbol associated with communion silver in the Church of England. Although this is an instance of significant Tridentine influence in England, Anglicans used the images for their common Christian themes rather than their particular Roman associations.

At the same time the avant-garde and their Laudian successors were keen to vindicate the continuity of the Church of England with its medieval predecessor through the uninterrupted episcopal succession rather than tracing the Puritan-inspired line of descent through proto-Protestants like Wycliffe, Hus, and the Waldensians. Those advocating more elaborate ceremonies and decoration of churches appealed to medieval precedent and adopted gothic forms. The College Chapel at Lincoln College, Oxford, was built in 1629-31 in a late perpendicular gothic style, and the apostles in the windows by Abraham van Linge stand under conventionally medieval canopies. Even in the midseventeenth century, surviving late Gothic forms remained a natural building style, as in the chancel screen commissioned in the 1630s by John Cosin at Sedgefield in County Durham. This growing awareness of the Church of England as a national catholic church with its apostolic Episcopal order, its strongly patristic theological identity, its own English liturgical use, and its local architectural tradition fostered a strong sense of common identity with the Gallican tradition which some leading churchmen, like Bishop Richard Montagu, worked hard to exploit. ${ }^{21}$

17 For their part, Gallicans were well aware of the Anglican contribution to their common patristic concerns. The great preacher and ecclesiastical statesman Jacques Benigne Bossuet, bishop of Meaux, was also patron of the Gallican patristic apologists. He and his allies acclaimed Bishop George Bull's work defending the Nicene faith, the Maurist Jean Mabillon recommended works by Anglican scholars for inclusion in monastic libraries. ${ }^{22}$ The orientalist and liturgist Eusèbe Renaudot familiarised Bossuet with the theology of Lancelot Andrewes and others so that Bossuet came to realise that Anglican teaching supported Christ's real (though not corporeal) presence in the Eucharist. Through the scholarship of Mabillon, Bossuet even came to affirm the validity of Anglican orders. ${ }^{23}$ 

chancel screens. The ideal church of the counter-reformation was the Jesuit church in Rome, the Gesú, with its shallow chancel and its absence of a screen, thus bringing the theatre of the mass close to the people. In many of the ancient churches and cathedrals, the medieval screen, or jubé, was being removed amidst the general enthusiasm for baroque furnishings. The focus on the high altar, preferably with a marble-columned ciborium or baldacchino, meant that many ancient furnishings and tombs were being swept away. Through Gallican influences, however, the principle of the screen did not disappear. John McManners notes, 'In some places the medieval work was replaced with a more delicately constructed barrier, one which broke up the view without obliterating it - a grille of ironwork in acanthus designs at Rieux, a row of Ionic pillars at Sens.' At Rouen the old screen was replaced by a new colonnade 'consisting of six marble shafts of antique workmanship, plundered long ago from the ruins of Leptis Magna in North Africa. ${ }^{24}$ Even some new churches built in the classical style in Paris, such as St Eustache, St Roch, and St Sulpice, were built with chancel screens.

Gallican theologians wrote spirited defenses of the place of choir screens in church. The liturgical theologian Jean-Baptiste Thiers published a Dissertations sur les jubés in 1688. Le Brun des Marettes, a Jansenist liturgist and expert on the liturgical traditions of NotreDame de Rouen, wrote (under the pseudonym De Moleon) in his Voyage liturgique de France of 1718, 'There is no higher act in the Christian religion than the Sacrifice of the mass; the greater portion of the other sacraments, and nearly all the offices and ceremonies of the church, are only the means or the preparation to celebrate or participate in it worthily.' This being the case, it was only natural that the place where the holy sacrifice was offered up should be set apart and railed off to enhance the people's reverence for the sacrifice. ${ }^{25}$ William Beveridge, the eminent patristic theologian and future Bishop of St Asaph, expressed himself in similar terms. When his parish church of St Peter, Cornhill in London, was rebuilt (1681) after the Great Fire of London, he insisted it had a chancel screen:

The Sacrament of the Lord's Supper being the highest mystery in all our religion, as representing the death of the Son of God to us, hence that place where this Sacrament is administered was always made and reputed the highest place in the church. And therefore, also, it was wont to be separated from the rest of the church by a screen or partition of network, in Latin, cancelli, and that so generally, that from thence the place itself is called the 'Chancel'.... It may be sufficient to observe at present, that the Chancel in our Christian churches was always looked upon as answerable to the Holy of Holies in the Temple; which, you know, was separated from the sanctuary or body of the Temple, by the command of God Himself. ${ }^{26}$

Wrought-iron chancel screens in Anglican and Gallican churches, like those in All Saints, Derby and Amiens Cathedral, have both the same rationale and appearance.

The chancel screen also provides a link to the leading English liturgical architect of the nineteenth century, Augustus Welby Pugin, who believed passionately in the liturgical necessity of screens to a Christian church. Pugin was the chief begetter of the Gothic Revival in a meteoric career (he died aged only 40) that changed the face and mind of British architecture. Converted to Roman Catholicism as a young man, his passion was to redeem the ugly, industrialising, laissez-faire England of his day by restoring the fabric and values and faith of an idealized medieval England. ${ }^{27}$

In his determination Pugin was particularly inspired by the neo-Gallican liturgists and historians of seventeenth- and eighteenth-century France who celebrated the particular 
traditions, rites, and ceremonies of the medieval French church as opposed to those of Rome. Pre-eminent among the authorities Pugin most frequently cites in his writings are Jean-Baptiste Thiers, Dom Edmond Martène, and Le Brun des Marettes. Just as these Frenchmen celebrated their own native traditions, so Pugin believed the English Church ought to revive the English traditions of the Sarum rite.

During the early years of his career as the architect of choice for a Roman Catholic Church regaining confidence about its place in English society, Pugin's enthusiasm for the Gothic swept all before him. He encouraged the church to look back to its days of medieval glory, and even the most enthusiastic Romanists, like Cardinal Wiseman, were convinced that this was the right way forward for English Catholics to assert their place in the mainstream of English life. Pugin had rich and complaisant patrons, like the Earl of Shrewsbury, who were prepared to indulge him; he had celebrity and the knowledge of his authority as the expert on Gothic architecture and he was buoyed up by the popular medieval romanticism of the time. Pugin took his passion for screens with him wherever he built a church. For a time, other future converts, led by Newman, shared his Gothic enthusiasm.

Once the new generation of Anglicans went over to Rome around 1845, however, their attitude to Pugin changed entirely. W.G. Ward became convinced that only doing things as Rome did could be acceptable and he became a vigorous opponent of medieval or Gallican usages and traditions. Newman had rejoiced in the Gothic of St Giles, Cheadle (the church that most fully exemplifies Pugin's ideals), when it opened in 1845; before 1841 , he had expressed repugnance with the architecture of Renaissance Rome. Now that he had become a Roman Catholic, he lost his interest in the Gothic and took a greater delight in the classical with every step he took toward Rome. He wrote of the Church of St Fidelis, Milan, in 1846,

It has such a sweet, smiling, open countenance - and the Altar is so gracious and winning - standing out for all to see, and to approach. The tall, polished marble columns, the marble rails, the marble floor, the bright pictures, all speak the same language. And a light dome perhaps crowns the whole ... so in the ceremonial of religion, younger men have my leave to prefer gothic, if they will be [sic] tolerate me in my weakness which requires the Italian. ${ }^{28}$

Newman came to prefer churches in the style that followed the Jesuit pattern of a shallow chancel, no screen, altar rails, by which the people could come closer to the altar than in a Gothic church and thus see and hear better. The style of the Oratory of St Philip Neri suited Newman perfectly; he had found an architectural and liturgical setting where he felt perfectly at home.

This change of heart led to a fierce quarrel between Newman and Pugin. For these two men, it was not simply a difference in architectural style, but also the liturgical and doctrinal implications that went with them. The argument became deeply personal. Frederick Faber, already an Oratorian, tore down the rood screen that Pugin had built for the church at Cotton Hall. Newman took to spelling 'screen' with a ' $\mathrm{k}$ ' to show his contempt for this medieval relic. ${ }^{29}$

Newman as an Oratorian believed that sight and sound were of the greatest importance in the Roman liturgy and that chancel screens blocked the people's sight of the sacrament. As long as English Catholics continued to focus on their own national architecture and traditions, they would lapse into the sins of the national church and fail to be properly Roman. Newman became so incensed by Pugin's Gothic intransigence that Newman went 
so far as to denounce Pugin to the Secretary of the Propaganda in Rome in 1848, accusing him of doctrinal inaccuracy and insinuating that he was a Gallican, schismatic, antiRoman and disloyal to the Pope. ${ }^{30}$ The Oratorians' hatred of Gothic became so overheated that Faber wrote that if St Philip Neri had possessed a 'dark Gothic cathedral' he would have 'pulled it down, and built another more to his own taste' and that therefore the Oratorians should 'pull down the buildings of our fathers', even Westminster Abbey if necessary. Faber believed that to convert the English, the Oratorians needed to offer the kind of light, popular, dramatic service like Benediction for which he believed Gothic churches were entirely unsuitable. ${ }^{31}$

The reversal was particularly painful for Pugin. He seemed to be losing all the credit and influence he had in the Catholic Church. His dream of a revived medieval Catholic England receded further and further. He did derive some comfort that many Anglicans remained faithful to the vision of a national catholic church. In his pamphlet, An Earnest Address on the Establishment of the Hierarchy in 1851, Pugin even expressed admiration of certain high Anglicans and gratitude that men like William Laud, John Cosin and John Hacket (bishop of Lichfield and Coventry and rebuilder of Lichfield Cathedral after the Civil War) had defended traditional liturgies and ceremonies and ancient buildings from the Puritans. 'The name of Hacket and Cosin may awaken a grateful remembrance in a Catholic heart', Pugin wrote. ${ }^{32}$

In his final riposte to the Oratorians, he wrote the most significant publication of his maturity, A Treatise on Chancel Screens and Rood Lofts in 1851. In it he showed how far he had moved beyond a monomaniacal devotion to Gothic as he explained the role of the chancel screen in the Church throughout the centuries, in buildings of all different architectural styles and periods. In a scarcely veiled attack on the Oratorians, Pugin claimed, 'We have now to contend for the great principles of Catholic antiquity, -tradition and reverence against modern development and display. It is not a struggle for taste or ornament, but a contention for vital principles. There is a most intimate connection between the externals of religion and the faith itself; and it is scarcely possible to preserve the interior faith in the doctrine of the holy Eucharist if all exterior reverence and respect is to be abolished. ${ }^{33}$ The Oratorian fixation on the necessity of seeing was, Pugin claimed, a capitulation to Protestant principles. He applied the title 'ambonoclast', or destroyer of screens, to Puritan and 'Paganisers' alike: 'It is remarkable what a similarity of feeling against screens is to be found among Puritans and Paganisers.' ${ }^{34}$

30 Far from being confined by medieval precedent, Pugin detailed how the screen had been part of churches from the time the first public churches were created. He drew on primitive antiquity (old St Peter's) as well as modern classical churches. He also made a point of including screens, whether Gothic in style or not, erected in the Church of England since the Reformation. Pugin explained how the discipline of the early Church taught that only those in a state of grace could safely look on the sacrament but that since then the church's discipline had changed. The church now taught that looking on the host was beneficial. Pugin did not have a problem with the emphasis on seeing the host but did not believe that this necessitated destroying old forms and devotions. He railed against 'the modern all-seing principle' and 'making the mass a sight' which, he thought, would 'lower the majesty of religion to the level of a common show'. ${ }^{35}$

31 Despite all the learning and powers of persuasion Pugin brought to his cause, his opponents were not to be convinced. Even those who had warmly supported him in the 
past, including Cardinal Wiseman, turned their support to the Romanists. The degree to which Pugin felt isolated within his own Catholic community may be inferred by the title of his last work, unpublished at his death: An Apology for the Separated Church of England since the reign of the eighth Henry. Written with every feeling of Christian charity for her children, and in honour of the glorious men she continued to produce in evil times. By A. Welby Pugin. Many years a Catholic minded son of the Anglican Church, and still an affectionate and loving brother and servant of the true sons of England's Church. ${ }^{36}$

With the development of the Oxford Movement into the Ritualist movement in the later nineteenth century, high church Anglicans became more than ever conscious of the sources of their ritual choices. By the early twentieth century, two tendencies (anticipated in the seventeenth century) had hardened into definite parties as mutually scornful of one another as Pugin and the Oratorians. ${ }^{37}$ The Anglo-Papalists, represented by the Society of St Peter and St Paul, nailed their colours to the Tridentine mast, choosing to worship according to the Roman rite and following the fashions prevalent in Continental Catholicism. ${ }^{38}$ They scorned the approach of their rivals at the Alcuin Club as 'British Museum religion'. These 'Prayer Book Catholics' strove to remain as faithful as possible to the rubrics of the Prayer Book, interpreting the 'ornaments rubric' as permitting, even requiring, the use of all the Sarum vestments, furnishings, and ceremonial current in the first half of 1549. ${ }^{39}$ St Cyprian's, Clarence Gate (1903), designed by Ninian Comper for the Sarum rite is a good example. With its gilt screens, 'English altars' hung with curtains on three sides, amply shaped medieval vestments, plainchant music sung from the rood loft, processions facilitated by the absence of fixed seating, this church provided the setting for the fullest expression of the ancient English rite. Its consecration rite was based on the mid-eighth century pontifical of Egbert, Archbishop of York. The historic affinity between Anglicanism and Gallicanism, based upon their common understanding of national catholic churches independent of Rome, was here expressed architecturally and liturgically. Ironically, Pugin's Gothic vision had come to be realized most fully in the Anglican Church he had left for Rome. ${ }^{40}$

Comper himself (like Pugin) later turned away from his strict adherence to the late medieval tradition towards incorporating the styles of liturgical planning of the early Church. He became a pioneer of the Liturgical Movement which, in the twentieth century, would render obsolete these battles about historical correctness. As in the seventeenth century, so the leaders of the Liturgical Movement in many denominations turned their gaze away from the Middle Ages toward the worship of the early Church. Never since the Middle Ages had the Eucharistic worship of the Church had such a strong family resemblance.

Most recently, however, there has been a revival of interest in historic forms of liturgy, inspired not least by the preferences of Pope Benedict himself. When he came to Britain in 2010, it was widely reported how moved he had been by the Anglican worship at Westminster Abbey - the papal spokesman Fr Federico Lombardi acknowledged that Pope Benedict had been 'impressed' by the 'richness' of the liturgy. Here was something from which Roman Catholics could learn. This would be the style of the Ordinariate. How ironic then, that his vision should be formed at the Abbey, whose worship remains shaped by the medieval Sarum tradition of Prayer Book Catholicism, for this is precisely the style that papalist Anglicans in England have most firmly rejected in favour of the modern Catholic style. 
Pope Francis has not the same interest in liturgical tradition as his precedessor, but his commitment to decentralise the Church and to share authority collegially with his brother bishops is evidence that the Gallican conciliar tradition shared with Anglicans may be a significant part of the future of the Roman Catholic Church. Whatever the future of the Ordinariate, we can be sure that Anglican and Roman styles of worship in the foreseeable future will continue to be shaped by the Gallican, Tridentine, and early Christian traditions.

\section{NOTES}

1. See the origins of this programme in Joseph Ratzinger, The Spirit of the Liturgy (San Francisco: Ignatius Press, 2000).

2. Anglicanorum coetibus, 4 November 2009.

3. Letter of His Holiness Benedict XVI to the bishops on the occasion of the publication of the publication of the Apostolic Letter 'Motu Proprio Data' Summorum Pontificum on the use of the Roman Liturgy prior to the reform of 1970, 7 July 2007.

4. Significant recent works on Gallicanism include Jacques M. Gres-Gayer, Le Gallicanisme de Sorbonne (Paris: Champion, 2002) and Emile Perreau-Saussine, Catholicism and Democracy: An Essay in the History of Political Thought (Princeton: Princeton University Press, 2011).

5. Kenneth Fincham and Nicholas Tyacke, Altars Restored. The Changing Face of English Religious Worship, 1547-c.1700 (Oxford: Oxford University Press, 2007). In addition, G.W.O. Addleshaw and Frederick Etchells, The Architectural Setting of Anglican Worship (London: Faber and Faber, 1948) remains a crucial resource.

6. Richard Hooker, of the Laws of Ecclesiastical Polity, Bk v, ch. 14, in The Works of that Learned and Judicious Divine, Mr Richard Hooker, ed. John Keble (Oxford: Clarendon Press, 1888), II, 51-52.

7. See Jaime Lara, City, Teple, Stage. Exchatological Architecture and Liturgical Theatrics in New Spain (Notre Dame, Ind: University of Notre Dame Press, 2004), ch. 4.

8. In Ezechielem explanationes et apparatus urbis ac templi Hierosolymitani commentariis et imaginibus illustrati (Rome, 1596-1604).

9. John Archer, 'Puritan Town Planning in New Haven' Journal of the Society of Architectural Historians 34 (2), (1975): 140-149.

10. A. K. Offenburg, 'Jacob Jehuda Leon (1602-1675) and his Model of the Temple' in J. Van den Berg and Ernestine G. E. Van der Wall, eds. Jewish-Christian Relations in the Seventeenth Century, (Dordrecht: Kluwer Academic Publishers, 1988), 95-115.

11. Stephen Porter and Adam White, 'John Colt and the Charterhouse Chapel', Architectural History 44 (2001): 228-236.

12. Arnold Hunt, 'The Lord's Supper in Early Modern England', Past \& Present, No. 161 (1998), 39-83.

13. Achsah Guibbory, Christian Identity, Jews and Israel in Seventeenth-Century England (Oxford: Oxford University Press, 2010), chap. 2.

14. The Theological Works of the Rev. John Johnson (Oxford: John Henry Parker, 1847), vol. 1.

15. See especially Pierre de la Ruffinière du Prey, Hawksmoor's London Churches: Architecture and Theology (Chicago: University of Chicago Press, 2000). 
16. Cited in C. W. Dugmore, Eucharistic Doctrine in England from Hooker to Waterland (London: S.P.C.K., 1942), 102. For further exploration into Temple motifs in Anglican churches, see Peter Doll, 'The Architectural Expression of Primitive Christianity: William Beveridge and the Temple of Solomon' Reformation and Renaissance Review 13.2 (2011): 275-306.

17. Jean-Louis Quantin, The Church of England and Christian Antiquity: The Construction of a Confessional Identity in the $17^{\text {th }}$ Century (Oxford: Oxford University Press, 2009); Paul Avis, In Search of Authority: Anglican Theological Method from the Reformation to the Enlightenment (London: Bloomsbury, 2014).

18. Peter M. Doll, ed. Anglicanism and Orthodoxy 300 Years after the 'Greek College' in Oxford (Oxford: Peter Lang, 2006); Judith Pinnington, Anglicans and Orthodox: Unity and Subversion 1559-1725 (Leominster: Gracewing, 2003).

19. Peter McCullough, 'Absent Presence. Lancelot Andrewes and 1662' in Stephen Platten and Christopher Woods, eds. Comfortable Words. Polity and Piety and the Book of Common Prayer (London: SCM, 2012), 49-68.

20. Graham Parry, The Arts of the Anglican Counter-Reformation: Glory, Laud and Honour (Woodbridge: The Boydell Press, 2006).

21. Anthony Milton, Catholic and Reformed. The Roman and Protestant Churches in English Protestant Thought 1600-1640 (Cambridge: Cambridge University Press, 1995), 263-269. For broader consideration of Anglican-Gallican links, see Peter Doll, Revolution, Religion, and National Identity. Imperial Anglicanism in British North America 1745-1795 (London: Associated University Presses, 2000), 22-29.

22. George Every, S.S.M., The High Church Party 1688-1718 (London: S.P.C.K., 1956), chap. 1, and Owen Chadwick, From Bossuet to Newman. The Idea of Doctrinal Development (Cambridge: Cambridge University Press, 1957), 13-16, 52-60.

23. W.J. Sparrow Simpson, A Study of Bossuet (London: S.P.C.K., 1937), 117-18. See chap. 10, 'Bossuet and the Church of England'.

24. John McManners, Church and Society in Eighteenth-Century France (Oxford: Clarendon Press, 1998), I, 442.

25. Quoted in Augustus Welby Pugin, A Treatise on Chancel Screens and Rood Lofts. Their Antiquity, Use, and Symbolic Signification (London: Charles Dolman, 1851), 3. Facsimile published at Leominster by Gracewing, 2005.

26. William Beveridge, 'The Excellence and Usefulness of the Common Prayer: Preached at the Opening of the Parish Church of St Peter's, Cornhill, the 27th of November 1681', in The Theological Works of William Beveridge, 12 vols., Library of Anglo-Catholic Theology (Oxford, 1842-46), vol. vi, 388.

27. The most recent biography of Pugin is Rosemary Hill's God's Architect. Pugin and the Building of Romantic Britain (London: Allen Lane, 2007). The author who best understands Pugin as a liturgical theorist is Christabel Powell, Augustus Welby Pugin, Designer of the British Houses of Parliament: The Victorian Quest for a Liturgical Architecture (Lampeter: Edwin Mellen Press, 2006).

28. Stephen Dessain, ed. The Letters and Diaries of John Henry Newman xi, (London: Thomas Nelson, 1961), 249. Newman to W.G. Penny, 24 September 1846.

29. Powell, Pugin, 282.

30. Ibid., 289-90.

31. Frederick William Faber, The Spirit and Genius of St Philip Neri: Founder of the Oratory. Lectures delivered at the Oratory, King William Street, Strand, (London: Burns and Lambert, 1850), 55-56.

32. Pugin, An Earnest Address on the Establishment of the Hierarchy, (London: Charles Dolman, 1861),

12.

33. Pugin, Screens, 3.

34. Ibid., 75.

35. Ibid., 3.

Revue Française de Civilisation Britannique, XXII-1 | 2017 
36. It is worth noting, however, that Pugin's Sarum spirit survived in parts of the English Catholic Church, particularly among the Benedictines. Anglican converts had a decisive influence on the buildings and worshiop of Downside Abbey. See Michael Hall, 'Thomas Garner and the Choir of Downside Abbey Church' and Aidan Bellenger, 'The Work of Sir Ninian Comper and Frederick Walters' in Aidan Bellenger, O.S.B., ed. Downside Abbey. An Architectural History (London: Merrell, 2011), 117-176.

37. Nigel Yates, Anglican Ritualism in Victorian Britain 1830-1910 (Oxford: Oxford University Press, 1999), ch. 7; Peter F. Aston, Fashions in Church Furnishings (London: Faith Press, 1960), chs. xxix, xxx.

38. Michael Yelton, Anglican Papalism. A History: 1900-1960 (Norwich: Canterbury Press, 2005); Anselm Hughes, The Rivers of the Flood (London: Faith Press, 1961).

39. Percy Dearmer was the scholar and theorist of the Prayer Book Catholics, whose work is summed up in the many editions of the best-selling Parson's Handbook from 1899 to 1960. Donald Gray, Percy Dearmer: A Parson's Pilgrimage (Norwich: Canterbury Press, 2000).

40. A definitive study of Comper is Anthony Symondson and Stephen Bucknall, Sir Ninian Comper (Reading: Spire Books with the Ecclesiological Society, 2006). On St Cyprian's, 87-97.

\section{ABSTRACTS}

In common with other churches of the Protestant and Catholic Reformations, the Church of England identified its own worship with that of the ancient Jewish Temple in Jerusalem and of the early Church. In the aftermath of Queen Mary's restoration of Catholicism, the Church of England's liturgical identity was also dominated by a severe Puritan reaction against all Catholic forms. In the last decade of Elizabeth's reign, however, an 'avant-garde' of clergy emerged committed to greater ceremonialism in worship according to the Book of Common Prayer. The Laudian high churchmanship that emerged from this beginning was a movement in tension, looking simultaneously to the Patristic Church, the pre-Reformation Church in England (with a strong strain of 'gothic survivalism') and the even more risky world of the continental baroque. From the seventeenth to the nineteenth centuries, the Church of England was conscious of affinities with the Gallican, nationalist tradition in the French Church, but at either end of this period the Tridentine baroque would also prove seductively fascinating to many Anglicans. The use of the chancel screen was frequently a touchstone of this debate.

While the Gallican tradition was effectively submerged within Roman Catholicism by the French Revolution and the First Vatican Council, the tension between the 'Gallican' and 'Tridentine' tendencies within Anglican high churchmanship remains alive to this day. In the nineteenth century, influential Anglican converts to the Church of Rome brought with them their contrasting convictions about the appropriate architectural setting for the liturgy. The architect A. W. N. Pugin, firmly committed to liturgical Gallicanism, advocated medieval music, architecture and Sarum ceremonial, while John Henry Newman and his fellow Oratorians insisted on an ultramontane liturgy and architecture. Through the creation of the Anglican Ordinariate within the Roman Catholic Church, the Anglican tradition continues to bear witness to the diversity of the Catholic tradition.

Comme les autres Eglises issues des Réformes protestantes et catholiques, l'Eglise d'Angleterre concevait sa liturgie en continuité avec celle du Temple antique de Jérusalem et de l'Eglise 
primitive. Après l'expérience de restauration par Marie Tudor du catholicisme, l'identité liturgique de l'Eglise d'Angleterre fut dominée par une violente réaction puritaine contre toute forme de pratique qui rappelait le catholicisme. Cependant, dans la dernière décennie du règne d'Elisabeth Ire, apparut une avant-garde cléricale acquise à plus de cérémonial dans le culte célébré selon les rites du Book of Common Prayer. De ces prémices, naquit ensuite la haute Eglise laudienne inspirée, non sans tensions, de l'Eglise des Pères, de l'Eglise médiévale anglaise (avec un goût pour les survivances gothiques) et du baroque continental auquel elle se risquait. Du XVIIe au XIXe siècle, l'Eglise d'Angleterre était très consciente de profondes affinités avec la tradition gallicane et nationale de l'Eglise de France, mais au commencement comme à la fin de cette période, le baroque tridentin a aussi fasciné et séduit maints anglicans. La présence ou non d'un jubé était à l'époque un des enjeux essentiels. Alors que la Révolution française et le premier Concile du Vatican sonnèrent la fin de la tradition gallicane au sein du catholicisme, les tensions entre les tendances "gallicane" et "tridentine» au sein de la haute Eglise anglicane restent vives encore aujourd'hui. Au XIXe siècle, d'influents anglicans, convertis à l'Eglise catholique romaine, y importèrent leurs désaccords sur le cadre architectural le plus approprié pour la liturgie. L'architecte A. W. N. Pugin, défenseur convaincu du gallicanisme liturgique, plaidait pour la musique et l'architecture médiévales ainsi que pour le cérémonial du rite de Salisbury, alors que Newman et ses amis oratoriens insistaient sur une liturgie et architecture ultramontaines. Par le biais de la création des Ordinariats anglicans au sein de l'Eglise catholique romaine, la tradition anglicane continue à porter témoignage de la diversité de la tradition catholique.

\section{INDEX}

Mots-clés: liturgie, anglicanisme, gallicanisme, catholicisme tridentin, architecture

Keywords: liturgy, Anglicanism, Gallicanism, Tridentine Catholicism, architecture

\section{AUTHOR}

PETER M. DOLL

Norwich Cathedral Library 